\title{
Evolution of a geotechnical model for slope design in an active volcanic environment
}

\author{
FM Weir PSM, Australia \\ MJ Fowler PSM, Australia \\ TD Sullivan PSM, Australia \\ M Kobler PSM, Australia \\ J Bu Newcrest Mining Limited, Papua New Guinea
}

\begin{abstract}
The Lihir gold mine is located at the base of the amphitheatre of the Luise volcano, which is a young strata volcano that has undergone sector collapse, phreatomagmatic activity and alteration. This creates a geotechnically complex environment due to the co-incidence of complicated lithologies, alteration, structural, geothermal conditions, existing landslides and high seismicity.
\end{abstract}

The rock mass model at Lihir comprises units that may be grouped into the following broad categories; surficial sediments, lithological and alteration. The structure model was developed understanding the geotechnically important strato-volcano regions which have been overprinted and modified by sector collapse and subsequent phreatomagmatic effects. The rock mass and structural understanding at Lihir are closely linked.

Groundwater flow at Lihir is driven by the interplay of rainfall recharge, deep geothermal upflow and the ocean. Due to the elevated rainfall rates occurring in the area, recharge is significant across the entire site. The groundwater and geothermal conditions are complex and this makes pore pressure estimations for slope stability some of the most complicated undertaken in modern mining practices around the world.

The geotechnical model comprises a view of the rock mass, structure and pore pressures. This paper presents the geotechnical model for pit slope design at Lihir gold mine with a focus on how our understanding of ground conditions and controls on slope stability has evolved over time.

Keywords: geotechnical model, volcano, diatreme, slope design

\section{Introduction}

For the design of an excavation, whether it is an open pit slope or a tunnel, an accurate geotechnical model is required to represent ground conditions at a site. The model needs to incorporate the important elements relevant to design and construction (Hencher 2012). A geotechnical model should include geology (e.g. lithology, alteration), structures (e.g. major structures, joints), hydrogeology (e.g. phreatic surface, hydrogeological units, flow regimes), rock mass characteristics (e.g. intact rock strengths, rock mass strength) and site hazards (e.g. landslides, earthquakes).

The Lihir gold mine is located on Lihir Island in Papua New Guinea and is part of the Tabar-Lihir-Tanga-Feni chain of volcanic islands (Figure 1). The Lihir island is a $20 \mathrm{~km}$ long by $13 \mathrm{~km}$ wide volcanic island which has been divided into five volcanic regions ranging in age from Pliocene to Pleistocene (Figure 1). The Ladolam gold deposit and the open pit are located within the caldera of the collapsed Luise volcano, on the east coast of the island (Figure 1). The caldera forms a significant topographic feature that surrounds the active mining area and associated infrastructure with steep natural slopes (Figure 2). 
The existing pit is about $2.2 \mathrm{~km}$ long and $1.6 \mathrm{~km}$ wide with a depth of about $300 \mathrm{~m}$ (relative to sea level). The focus on this study is the geotechnical model of the northern mine area (NMA), where mining is planned to progress through a series of lateral cutbacks.

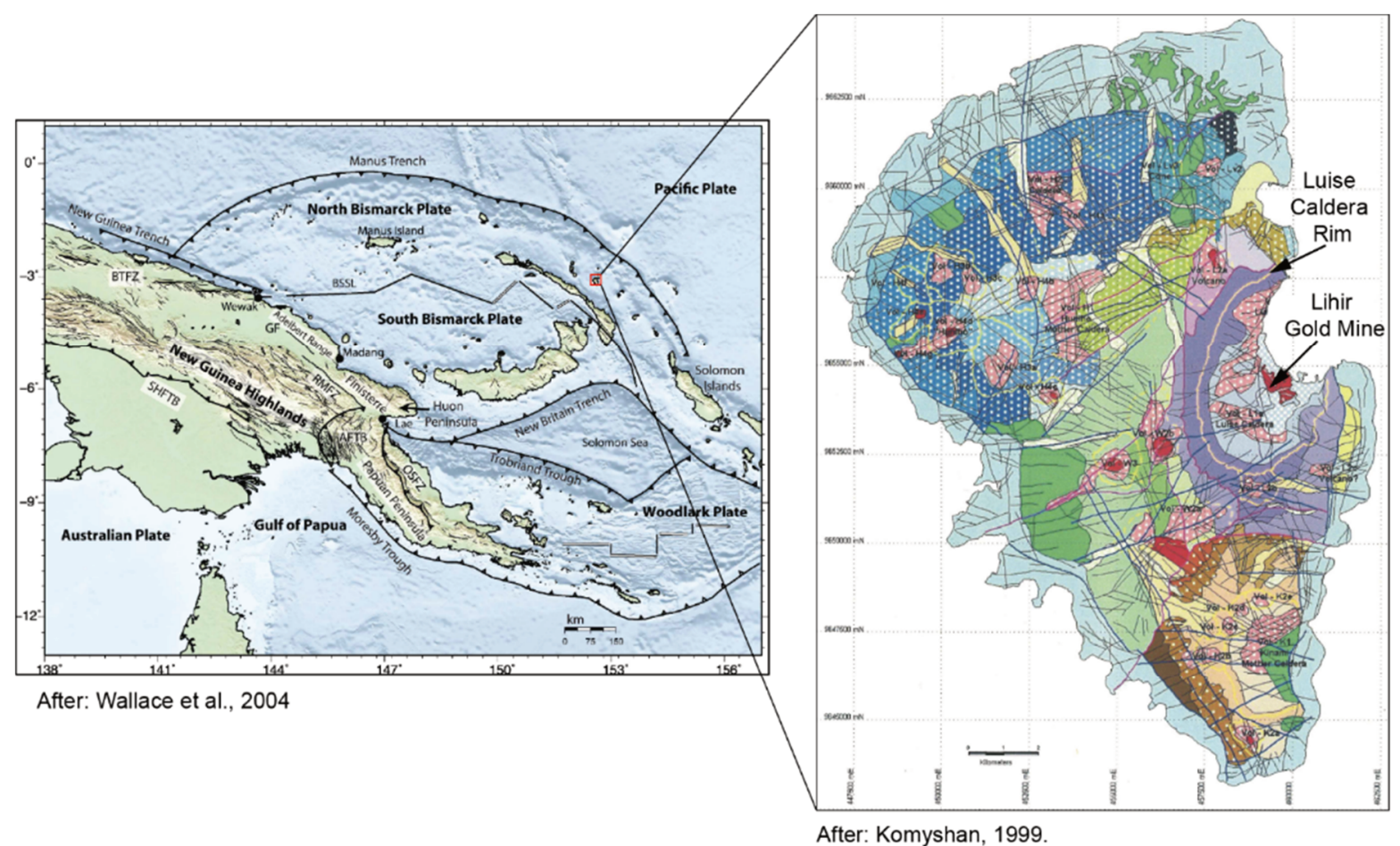

Note: Legend relevant for Luise Caldera

After: Komyshan, 1999

\begin{tabular}{|c|c|c|c|}
\hline egend & & & \\
\hline — Major faults & COS Alt, Alteration Zone & L1m, Volcanics (Luise Volcanic Units) & L5, Pyroclastics (Luise Volcanic Units) \\
\hline Major drainage & Gfd. Limestone & L2, Pyroc astics (Luise Volcanic Units) & Crater Lake Sediments \\
\hline Afn, Alluvial Fan & Int, Intrusives & L3, Pyroclastics (Luise Volcanic Units) & \\
\hline Agl, Alteration & L1, Undifferentiated Volcanics (Luise Volcanic Units) & L4, Pyroclastics (Luise Volcanic Units) & \\
\hline
\end{tabular}

Figure 1 Tectonic and regional setting of the Lihir gold mine

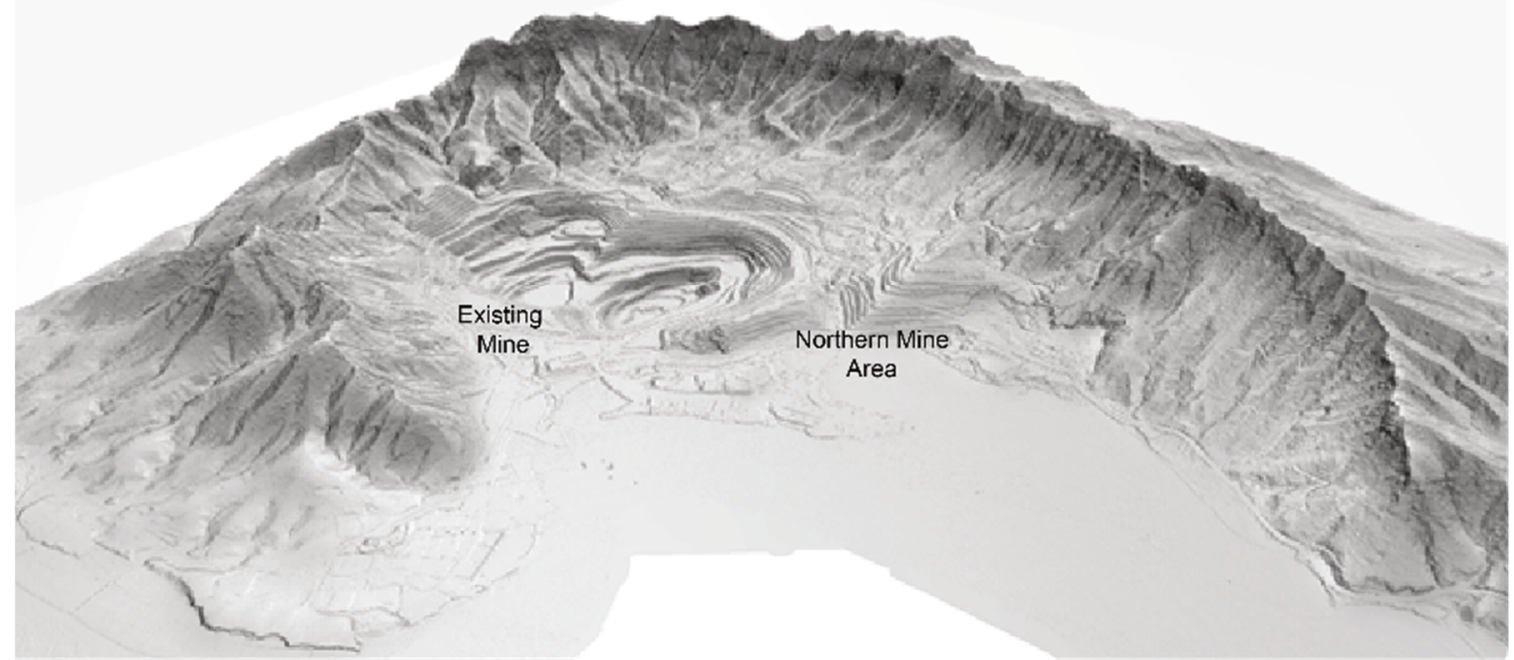

Figure 2 Oblique view towards the southwest of Lihir gold mine and the Luise Amphitheatre, 2009

\section{Data}

The field investigations and resulting data sets available for the geotechnical model and slope design study are extensive. Geotechnical data from nine drilling campaigns since 1999 is the primary data source. 
This borehole dataset consists of some 288 holes and 39,200 metres of geotechnically logged core. Additional datasets include:

- Acoustic televiewer (ATV) images from 89 of the 288 geotechnical boreholes. ATV data has been collected at Lihir since 2008 to give reliable structure orientation data. This dataset was supported by core orientation data.

- Mapping (face mapping and geomorphology) and photographs from existing and past pit exposures and the natural caldera slopes.

- Photogrammetry of some existing pit faces.

- Geophysical data including seismic refraction lines and downhole geophysics.

- Extensive records of slope performance in terms of failure records, some back analyses and prism data.

- An extensive geomechanical laboratory testing database for both soil and rock mass units.

- In situ testing including standard penetration tests, cone penetration tests and dilatometer tests (DMTs).

- A database of 438 vibrating wire piezometers (VWPs) with some 266 currently active.

- Hydrogeological field testing, including historic small- and large-scale testing and recent injection tests.

A summary of borehole data quantum over time for the NMA is provided in Table 1 . The current geotechnical model is founded on a large, comprehensive dataset with good spatial coverage.

Table 1 Borehole data collection phases in the northern mine area

\begin{tabular}{llllllll}
\hline & $\begin{array}{l}\text { Study year } \\
\text { 1999-2005 }\end{array}$ & $\mathbf{2 0 0 8 - 2 0 1 0}$ & $\mathbf{2 0 1 0 - 2 0 1 2}$ & $\mathbf{2 0 1 3 - 2 0 1 4}$ & $\mathbf{2 0 1 6 - 2 0 1 7}$ & 2017-2018 & Total \\
\hline $\begin{array}{l}\text { Geotechnical } \\
\text { boreholes (no.) }\end{array}$ & 10 & 37 & 102 & 15 & 19 & 105 & 288 \\
$\begin{array}{l}\text { Boreholes with } \\
\text { acoustic } \\
\text { televiewer (no.) }\end{array}$ & 0 & 19 & 23 & 7 & 18 & 22 & 89 \\
\hline
\end{tabular}

\section{Geotechnical model}

\subsection{Conceptual model}

The development of the conceptual model is an essential step in any geotechnical model. It provides a hypothesis that all available data can be tested against. The conceptual model for the Luise volcano was developed using modern analogues from similar volcanoes and a combination of historical and current exposures at the Lihir mine.

The modern analogues reviewed included:

- Mt St Helens: a modern example of large-scale sector collapse of a strata volcano. The sector collapse (a large landslide) was triggered by an earthquake, which caused the exposure of the magma chamber, and an explosive eruption occurred. Following this collapse, new volcanic activity commenced within the caldera. 
- White Island: an analogue for the processes and volcanic forms post-sector collapse. The locus of eruptive activity is variable and over the years numerous vents, maars and collapse craters have formed and coalesced.

Both examples highlight the dynamic, evolving, and overprinting nature of young volcanoes.

The sector collapse exposes the central core of the volcano to the atmosphere resulting in phreatomagmatic activity, the mixing of surface waters with magma and super-heated steam and water under pressure. The combination of reduced vertical stress due to the collapse unloading and phreatomagmatic activity is also associated with diatreme formation. Diatremes are generated by pulses of magma mixing with external water, rapid transfer of heat from magma to water, and explosion of the mixture. An example of cross-section is presented in Figure 3.

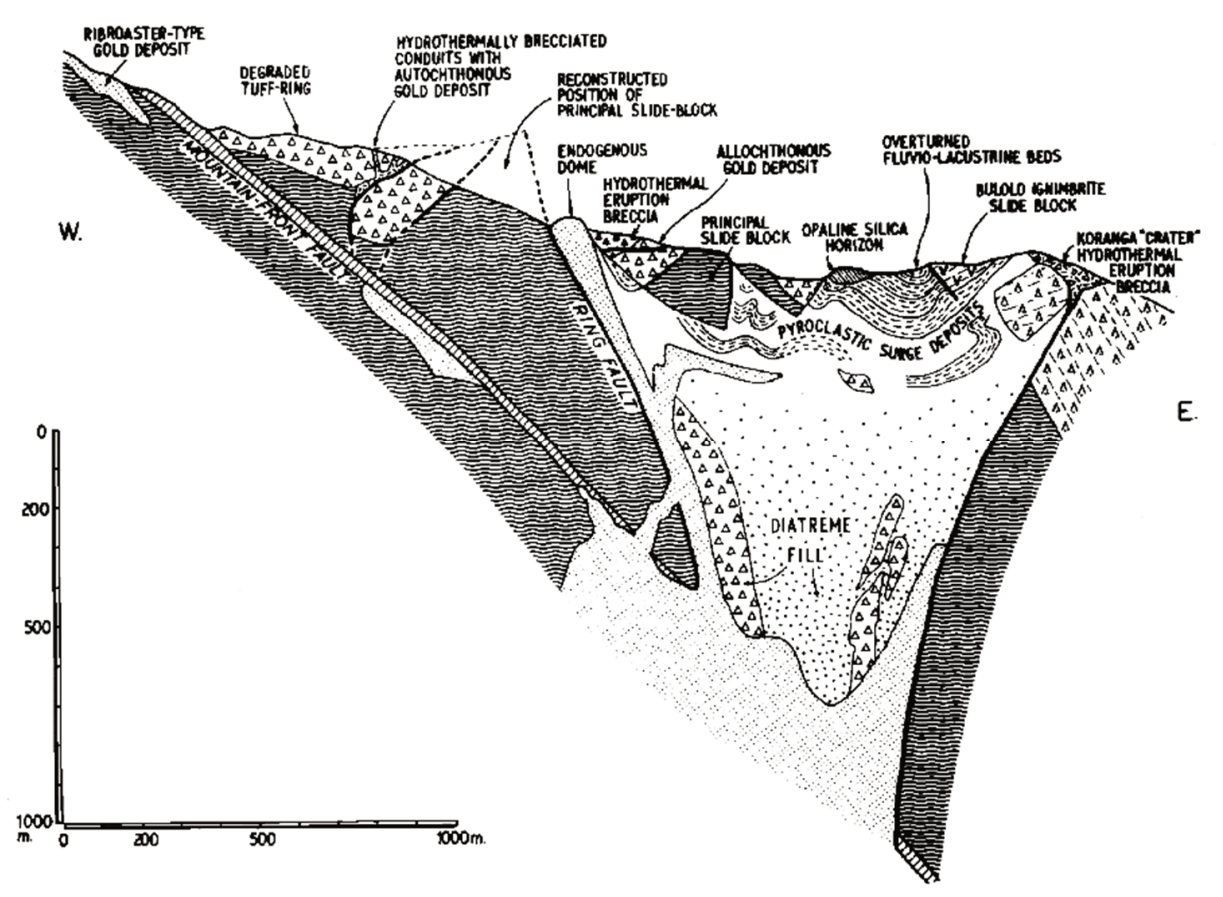

Figure 3 Schematic section of the Wau Maar-diatreme in Papua New Guinea (Sillitoe et al. 1984)

Many diatremes are localised along regional structures as their explosive energy exploits the structures. The diatreme contacts are typically sheared due to forceful emplacement and then compaction settlement. However, this shearing tends to die out with depth (Figure 3). There is also the potential for diatreme parallel structures, often formed concentrically. Ring faults are also common.

Diatremes that form explosively may leave a crater. The crater can become deeper due to subsidence of the diatreme deposits. This subsidence cone or residual crater soon forms a Crater Lake, which is then often filled with epiclastic and/or fluvio-lacustrine sediments.

\subsection{Luise Caldera geology and geological history}

The Luise Caldera comprises a sequence of agglomerates, tuffs and basalts intruded by monzonite. The lithologies have typically been overprinted by various hydrothermal events, resulting in significant alteration from their primary rock types. The porphyry alteration stage of the volcano resulted in extensive alteration within the original volcano, pressure-induced weakening of the 1,200 $\mathrm{m}$ high edifice, and eventual caldera collapse about 350,000 years ago.

Collapse of the Luise volcanic edifice likely occurred as sideways unroofing, in which the northeastern flank of the volcano was removed in one or more catastrophic slope failures (Corbett \& Leach 1998). This resulted in intrusion and quenching by sea water; extensive normal listric faulting, large-scale magmatic-hydrothermal 
and phreatomagmatic explosive breccias and diatreme breccias, pervasive alteration of rock, and precipitation of structurally controlled mineral deposits (Hunt 2002; Blackwell 2010). This understanding is consistent with the conceptual model in the previous section.

The complicated geological history of multiple deformation episodes and pervasive alteration makes it difficult to distinguish among the various breccia types at Lihir and inhibits the development of a lithological model.

Recent alluvial, colluvial and marine sediment sequences overlie the older volcanogenic stratigraphy.

\subsection{Geotechnical units}

The soil and rock mass model for the NMA has been developed from a framework of historical studies and recent site investigations. It represents the continuing evolution in the understanding of ground conditions at Lihir. Early geotechnical models for the site were based around the existing southern mining area, where the geotechnical units were found to largely relate to the ore type/alteration model. However, as the model and mining progressed away from the volcano central core, the relationship that the model has had to evolve to incorporates the effects of late-stage phreatomagmatic activity.

The available borehole data in the NMA was used to assess intervals of core with similar geotechnical character, termed here 'geotechnical units'. The current geotechnical model comprises units that may be grouped into the following broad categories:

1. Surficial sediments including colluvium, landslide colluvium and near shore sediments.

2. Lithological

a. Diatreme breccias: Polymictic matrix-supported breccias, with a dark grey muddy matrix. Fresh to altered depending on the age of diatreme.

b. Crater Lake deposit: An alternating succession of diffusely bedded and normally graded mudstone, sandstone and conglomerates. Organics locally present.

c. Unaltered volcanic rocks: Igneous lava flows intercalated with agglomerates and epiclastics related to the flanks of the volcano.

3. Alteration

a. Argillics: Soils and extremely weak to medium strength rocks (International Society for Rock Mechanics system), related to epithermal stage alteration. The intensity of alteration decreases with depth.

b. Transitional units: Hydrothermally altered breccias and igneous rocks with a high proportion of vughs. Medium to high strength rocks.

c. Anhydrite sealed: Magmatic and hydrothermal breccia and intrusives, with anhydrite alteration/veinin. High strength rocks, alteration related to porphyry stage alteration.

All of the available data was used to create a 3D model of the geotechnical units. An oblique view of this model is shown in Figure 4 and illustrates the vertical relationship between some of the units. 


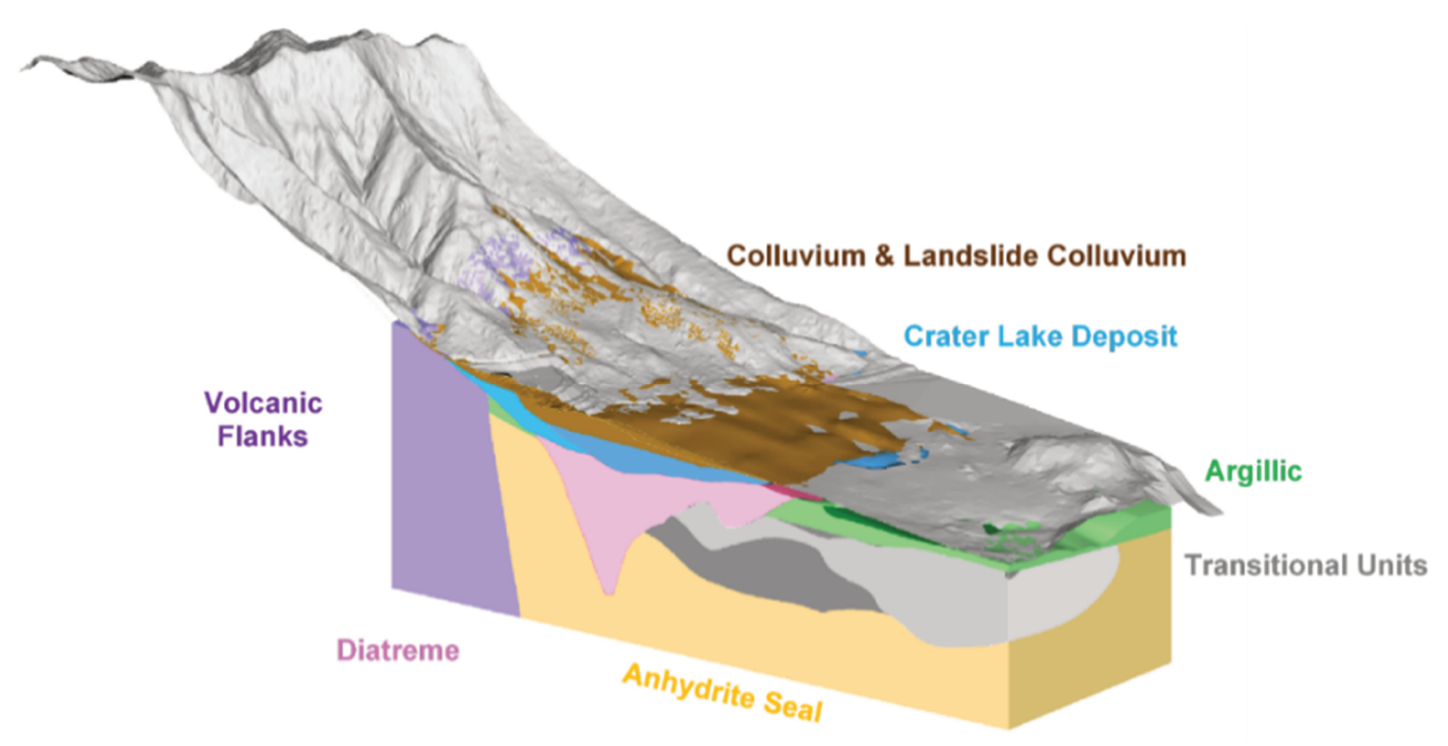

Figure 4 An oblique view of a slice through the 3D rock mass model

Soil strengths were established from both in situ testing and laboratory testing. Rock mass strengths have been derived using GSI, laboratory and logging data. Both the geometry and strengths of these units were an input to the stability assessments.

The remainder of this section focuses on diatremes and Crater Lake deposit as these units are considered critical for slope design in the NMA.

\subsubsection{Diatremes}

The diatremes in the Luise volcano cover three approximate periods or phases in the volcanic process, which also reflect specific characteristics:

1. Very fine-grained older: The older diatremes are harder to identify because they have been impacted by many of the volcanic processes. Their bounding structures are difficult to identify and these do not appear to be continuous. In many instances, the presence of the diatreme can only be defined by grain size, grain fabric and lithology.

2. Intermediate: Examples are evident on the east wall of the existing pit. All have intruded through the stronger rock mass of the central core region. They are typically weaker than the surrounding rock and bounded by structure.

3. Younger: The character of these features is typically:
a. Matrix.
b. Low strength rock mass and structure.
c. Flat, curved structures.
d. Sheared, slickensided, clay infill planes along contacts.

The first detailed characterisation of a large intermediate/young diatreme was identified by Blackwell (2010) in the existing mine area (Lienetz Diatreme, Figure 5). The diatreme is a polymictic, accretionary lapilli-bearing, matrix-supported breccia. Since 2010, with additional drilling data, model refinement has focused on the diatreme boundaries, northern extent and character. 


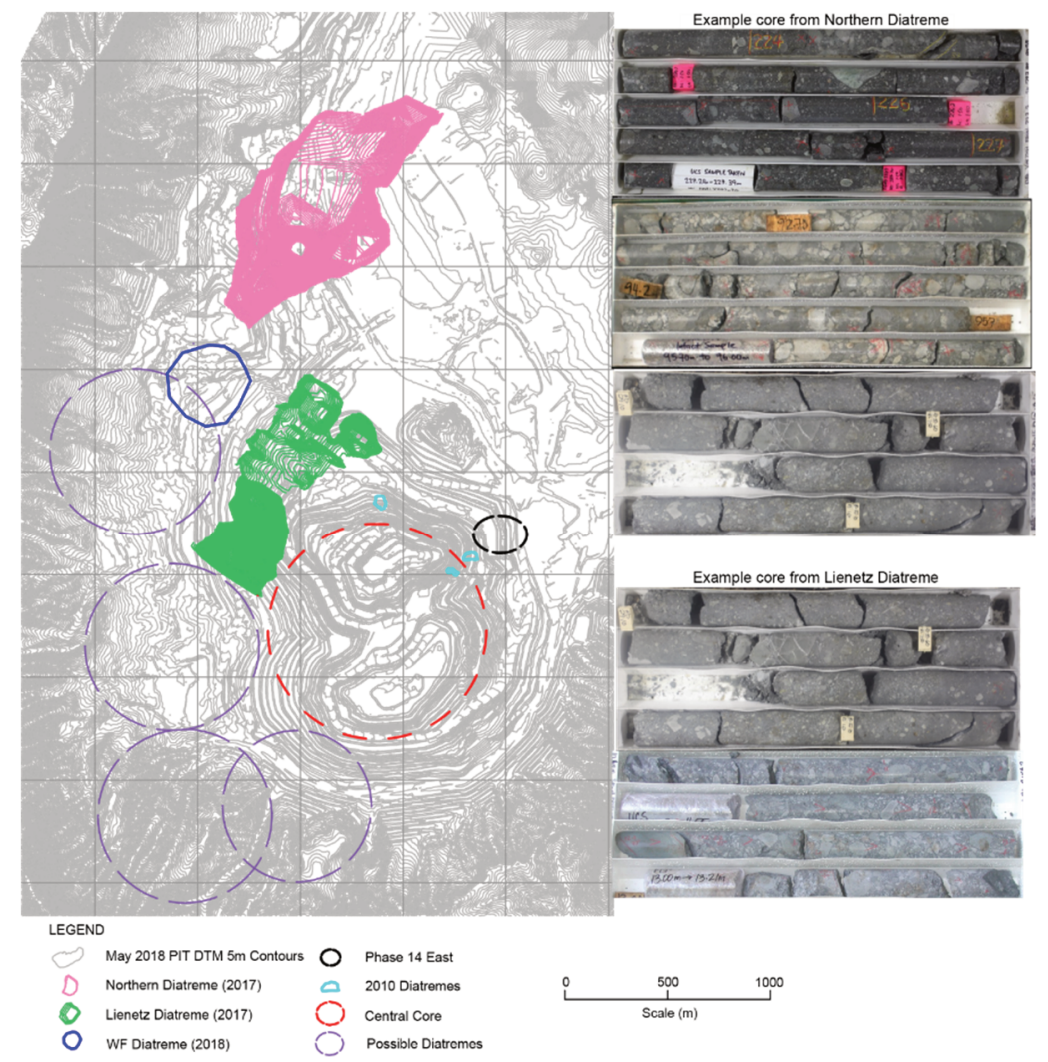

Figure 5 Identified and interpreted diatremes at Lihir

The northern diatreme is the largest of the discordant breccia bodies modelled in the Luise volcano (Figure 5). This diatreme will form a large portion of the final pit north wall. It is characterised as a polymictic matrix supported breccia with a dark grey muddy matrix and commonly white coloured andesitic clasts. The diatreme is interpreted as relatively young as it is largely unaltered or weakly altered. The northern diatreme was identified in 2017 as a sub-division of a zone modelled in 2012. The 2012 model encapsulated all areas likely to contain diatreme breccia in the NMA. The northern diatreme is overlain by the Crater Lake deposit (Figure 5), discussed in the following section.

A number of other possible young diatremes have also been inferred from the topography and exposures (Figure 5). These typically lie along the western side of the caldera. The location of the newly identified Phase 14 East diatreme shows the potential for other young diatremes to also be present to the east of the central core. Importantly, young diatremes do not occur in the central core. The shape of the Lienetz and northern diatremes (with a splayed sill feature extending to the north) and the location of other young diatremes implies that the underlying basement structures have played a role in the localisation of diatreme intrusions.

A review of site-wide historical slope performance showed that large-scale slope instability to date has been related to diatremes (or argillics) with pore pressures an important influence. The failure mechanisms relating to diatremes are variable but commonly include structure. Adverse structure conditions may be expected with the diatreme. While the exact location of any such structures are difficult to predict they show a shallow to moderate dip, curved, clay-filled and variably sheared with low strength. The keys for interpretation and prediction is to use the characteristic signatures of the younger diatremes to identify them, to understand the structural patterns associated with diatremes and where such structures typically develop then use ATV data to build and refine the structure model for that location. The structures within the diatreme are commonly emplacement related. The identification of the young diatremes from core photos is an important tool for predicting areas of increased risk of pit slope instability. 


\subsubsection{Crater Lake deposit}

A basin termed Crater Lake deposit (CLD) is located in the NMA, overlying the northern diatreme (Figure 4). The CLD comprises an alternating succession of organic-rich, diffusely bedded and normally graded mudstone, sandstone and conglomerates. They are distinguished by their overall fine grain size with a predominance of mudstone facies. Bedding is sub-horizontal in most of the deposit, which is atypical of the rest of the site. Shell fragments have not been identified. The sediments are marginally lithified with strengths varying from soil to weak rock. Overall, the basin fines to the north-northeast with the mudstone thickening to the north and northeast while the coarse sandstone and conglomerate thin in the same direction.

The basin is inferred to have been an eruption crater, which has been infilled with sediments, tuff and epiclastic deposits. The CLD was first identified in 2009 from correlation between a limited number of boreholes in the area. The presence of a sedimentary basin with soil layers has significant potentially implications for pit stability. Consequently, further study was undertaken in 2010 with a detailed model developed for the deposit from graphic facies logging of 22 boreholes. The graphic logging method displays grain size along the horizontal axis and depth on the vertical axis. The graphic logging technique is used widely in sedimentology and volcanology and complete descriptions of the method can be found in a number of resources including McPhie et al. (1993) and Gifkins et al. (2005). Figure 6 presents an example of a graphical facies log from the study.

Weak (soil strength) layers that could be identified in core photos were also recorded on facies logs. The identified layers were put onto the working interpretive cross-sections to identify possible correlation between boreholes.

Five broad geological facies were identified in the 2010 study ranging from clayey sands to gravels. The stratigraphic column is presented in Figure 7. An example of the facies model on one of the sections utilised for model development is presented in Figure 8.

With a significant increase in the number of boreholes within the deposit, the model was revisited in 2012. For the 2012 study, an additional 23 holes were available so that there were some 45 holes facies logged within and around the deposit.

The 2012 model update found that the original facies model was relatively robust, with refinement of the basin geometry and some additional anomalous zones delineated. The anomalous zones were those where the facies are disrupted, which is interpreted to be a result of late-stage hydrothermal activity, faulting or phreatomagmatic activity.

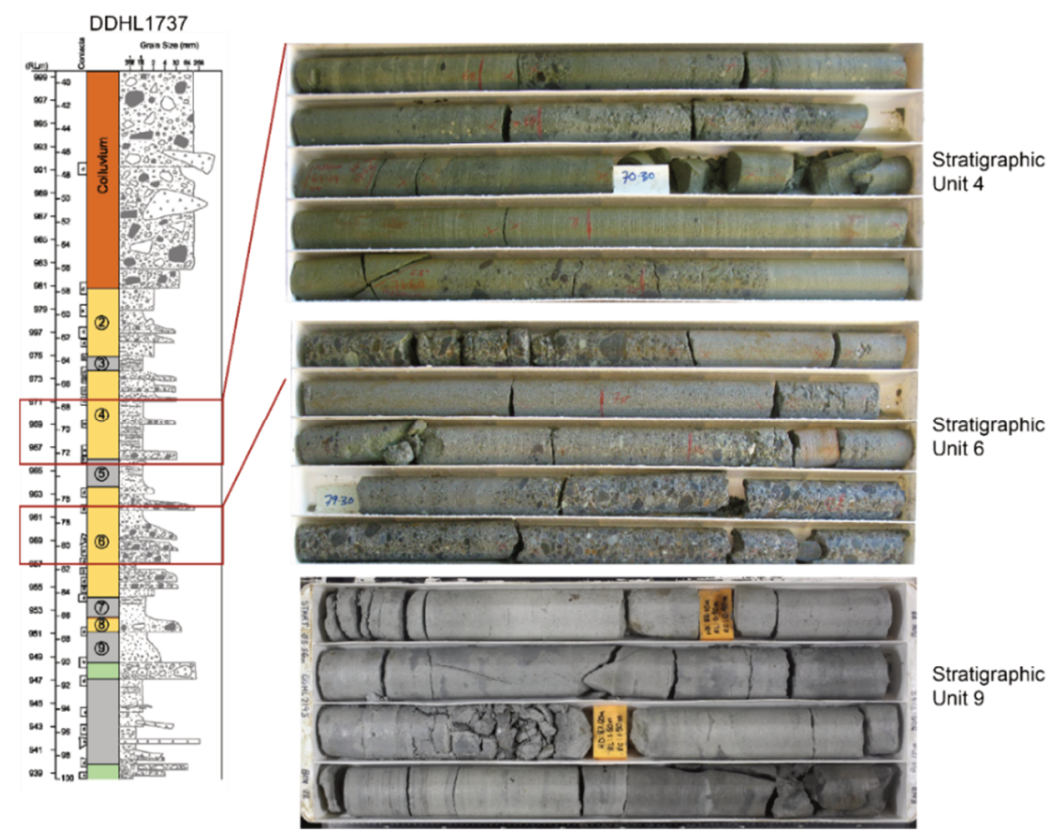

Figure 6 Example of a graphic facies log of a borehole in the Crater Lake deposit 


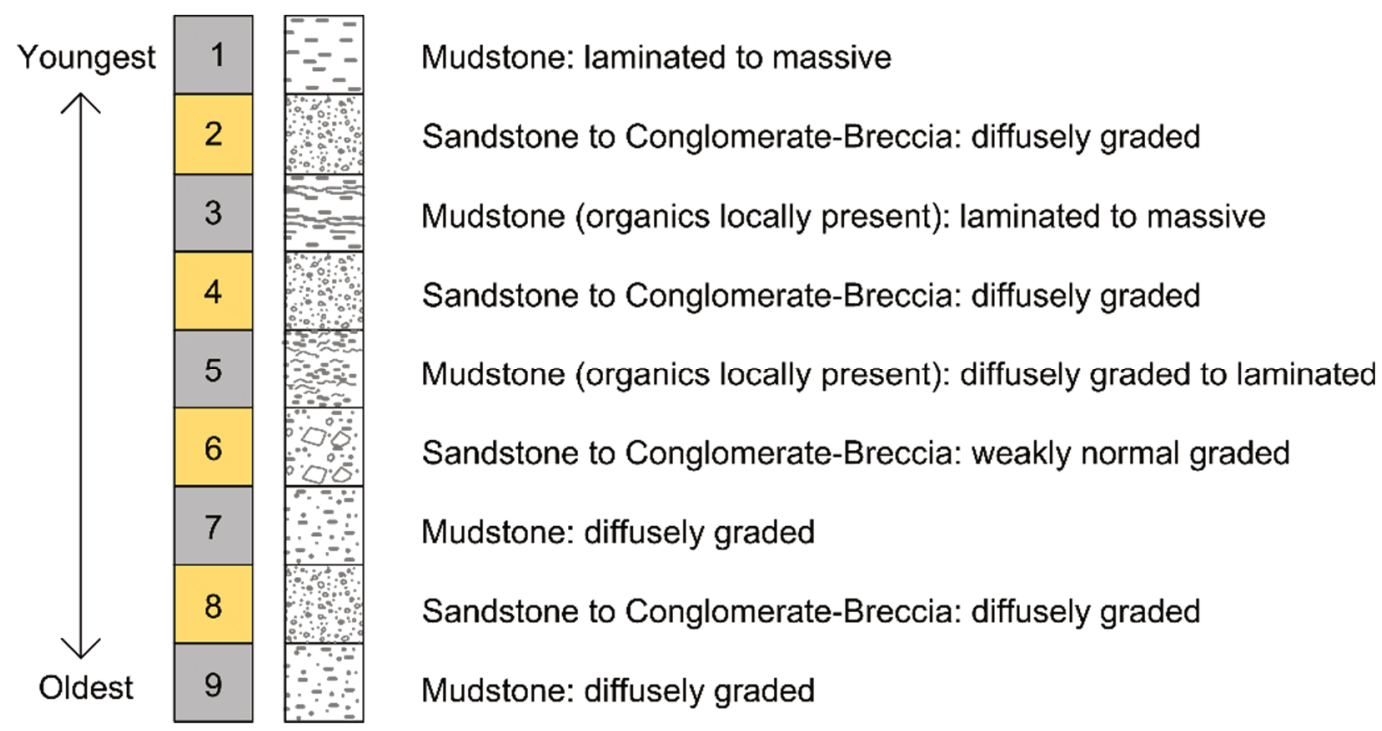

Figure 7 Stratigraphic column of the Crater Lake deposit

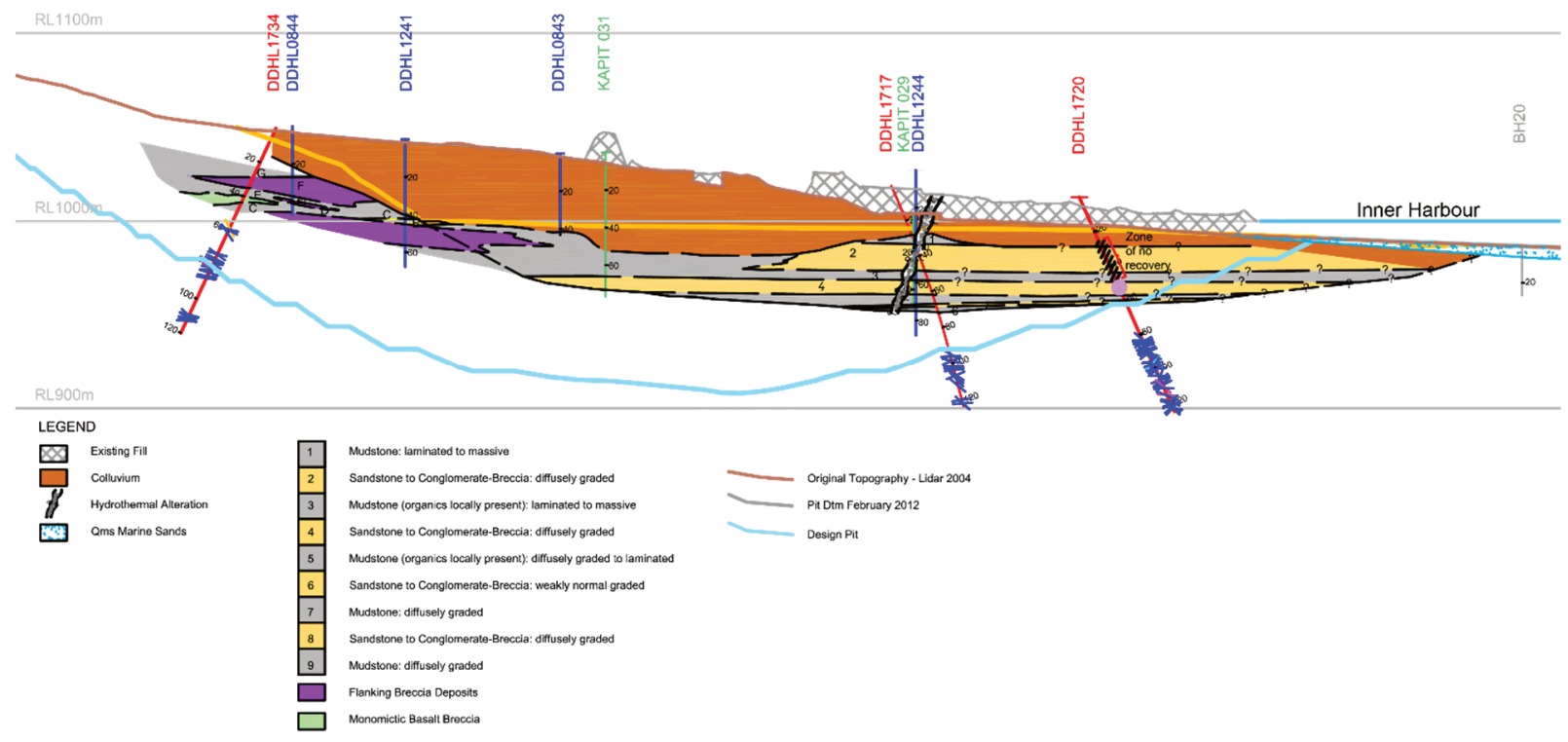

Figure 8 East-west cross-section showing the Crater Lake Facies model

As part of the 2017-2018 site investigations an additional 29 boreholes were drilled within and around the margins of the CLD. This site investigation improved data coverage and model reliability (Figure 9). The additional borehole data available in this study again showed the facies model to be robust with only minor refinements to the basin geometry. 


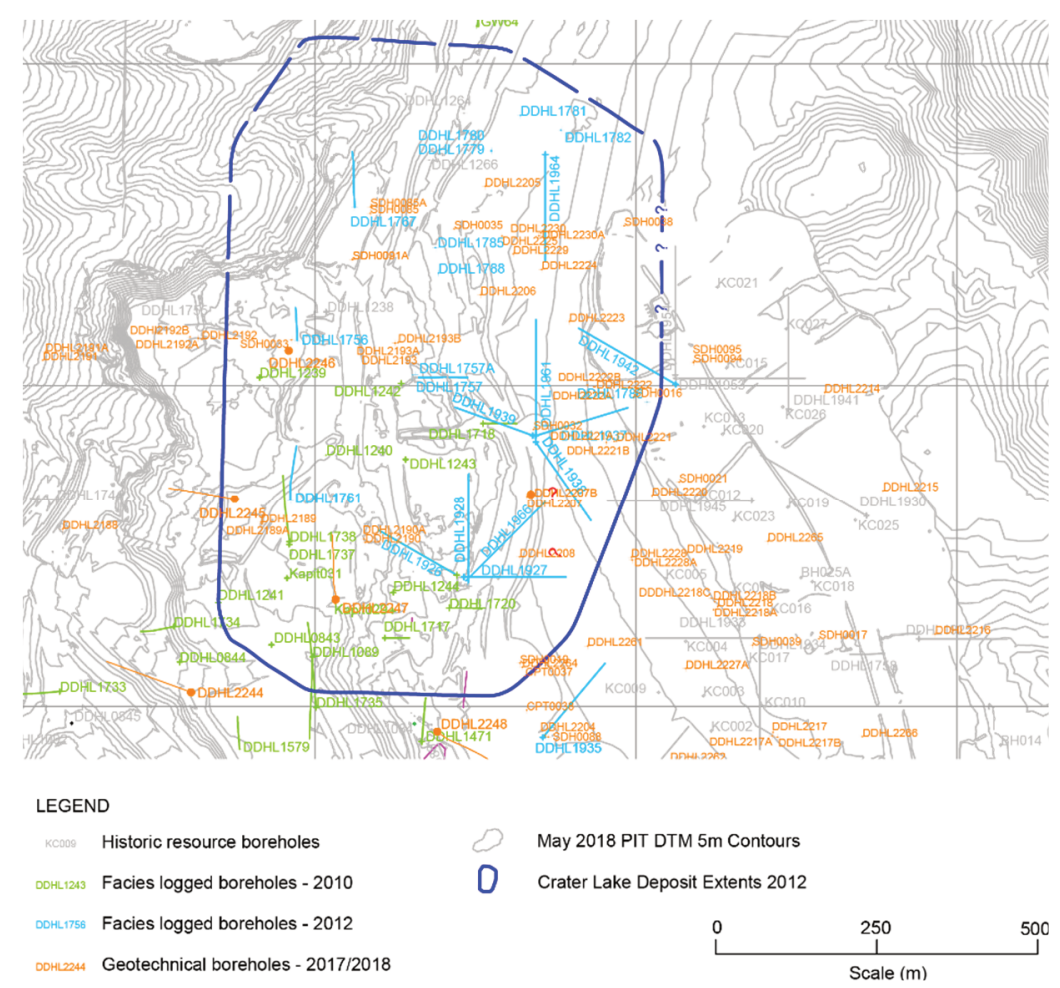

Figure 9 Crater Lake deposit borehole data coverage

The most notable evolution in the model relates to the understanding of structures in the deposit, particularly faulting. The 2010 study interpreted the unit as being relatively undisturbed, with minor evidence of the sediments being crosscut by some structure and restricted zones of significant alteration, possibly associated with late-stage hydrothermal or intrusive activity. However, it was noted that individual beds did not align perfectly between boreholes, perhaps due to post-depositional deformation, such as faulting.

The 2012 model update identified a number of possible faults and zones of jointing from borehole core photos. The additional data from 2017-2019 also indicates more adverse structural conditions than the 2012 model, with moderately dipping shears and joints in several boreholes. These boreholes are distributed variably across the domain and the patterns are consistent with settlement of weak sedimentary rocks. These conditions are considered a conservative representation of the rock mass with adverse implications for slope design in terms of forming release planes to allow sliding on horizontal weak beds.

In 2010, a number of possible models were considered for the origin of the basin, from deposition in a shallow Maar Crater Lake that formed above a diatreme, to deposition in an open or closed barrier basin environment. With further understanding of phreatomagmatic activity at Lihir, data collection and identification of the underlying northern diatreme in 2017 the deposition environment is now confirmed.

Of particular geotechnical importance for pit slope design are the:

- Laterally persistent nature of the stratigraphic units.

- Presence of weak beds (both observed and interpreted based on extensive zones of core loss in historic drilling).

The primary implication from this is that subsequent engineering analyses should consider laterally persistent horizontal weak layers. Anisotropic strengths were adopted to represent the reduced strengths parallel to bedding.

This is likely to result in a mechanism of sliding on bedding with failure either through rock mass or along faults in the sub-vertical release plane. The existing overlying landslide deposit is a translational landslide, interpreted to have failed via this mechanism (Figure 8). 


\subsubsection{Summary}

The evolution of the geotechnical model as it relates to diatremes and the CLD is summarised in Table 2.

Table 2 Geotechnical model Evolution for the Crater Lake deposit and diatremes at Lihir

\begin{tabular}{|c|c|c|}
\hline Year & Crater Lake deposit & Diatremes \\
\hline 2009 & $\begin{array}{l}\text { New geological unit identified from preliminary } \\
\text { geotechnical investigations in NMA. } \\
\text { Identification of sub-horizontally bedded soil layers. } \\
\text { Recognition that these layers likely contributed to a } \\
\text { landslide in } 2005 .\end{array}$ & $\begin{array}{l}\text { Identification of possible diatremes on } \\
\text { natural slopes based on remote sensing. }\end{array}$ \\
\hline 2010 & $\begin{array}{l}\text { Specific CLD study, including facies logging of } 21 \\
\text { boreholes. } \\
\text { Substantial core loss in a number of boreholes impacting } \\
\text { model confidence. } \\
\text { Development of stratigraphic column and facies } \\
\text { correlations on cross-sections. } \\
\text { Interpreted to be relatively undisturbed. } \\
\text { Southern and western margins of the basin relatively well } \\
\text { defined while the northern and eastern margins more } \\
\text { poorly defined. } \\
\text { Three possible models for formation. } \\
\text { 3D model of CLD geometry developed. }\end{array}$ & $\begin{array}{l}\text { Identification of small young diatremes in } \\
\text { existing pit faces } \\
\text { Identification of Lienetz Diatreme by } \\
\text { Blackwell. Well understood margins, except } \\
\text { for the northern extent. 2D cross-section } \\
\text { model. }\end{array}$ \\
\hline 2012 & $\begin{array}{l}\text { Facies logging of an additional } 23 \text { boreholes drilled. } \\
\text { Structural orientation data coverage relatively poor } \\
2010 \text { facies model was robust with some additional } \\
\text { disturbed zones delineated. } \\
\text { Refinement of the deposit geometry, confirmation of the } \\
\text { eastern extent and extrapolation to the north } \\
\text { Update of 3D model. }\end{array}$ & $\begin{array}{l}\text { Development of coarse model for diatremes. } \\
\text { 3D shape encapsulating a volume where } \\
\text { increased likelihood of intersecting diatreme } \\
\text { breccia. }\end{array}$ \\
\hline $\begin{array}{l}2016- \\
2017\end{array}$ & $\begin{array}{l}\text { No additional drilling in this unit, no change to model. } \\
\text { Confirmation of mode of formation with identification of } \\
\text { northern diatreme. }\end{array}$ & $\begin{array}{l}\text { Lienetz Diatreme - improved confidence in } \\
\text { northern extent, development of 3D model } \\
\text { Northern Diatreme - identification from } \\
\text { existing borehole data, underlies the CLD, } \\
\text { characterisation and 3D model development. }\end{array}$ \\
\hline $\begin{array}{l}2017- \\
2019\end{array}$ & $\begin{array}{l}\text { Additional } 29 \text { geotechnical boreholes, improved drilling } \\
\text { techniques and better core recovery. } \\
\text { Facies model robust and soil strength beds encountered } \\
\text { at depth, consistent with existing model. } \\
\text { Minor refinements to modelled extents. } \\
\text { Data gap still persists in northern margin of deposit; } \\
\text { however this is a significant distance from the proposed } \\
\text { pit crest. } \\
\text { More adverse conditions than the } 2012 \text { model, with } \\
\text { moderately dipping shears and joints in several } \\
\text { boreholes. }\end{array}$ & $\begin{array}{l}\text { Development of classification system (old to } \\
\text { young) and identification that younger } \\
\text { diatremes are likely to adverse structure and } \\
\text { rock mass conditions. } \\
\text { Further characterisation of diatremes, } \\
\text { including understanding of the structural } \\
\text { patterns. } \\
\text { Additional drilling confirmed modelled } \\
\text { locations of major diatremes to be robust } \\
\text { Identification of small diatreme in existing pit, } \\
\text { with low angle, curved structure resulting in } \\
\text { slope movement. }\end{array}$ \\
\hline
\end{tabular}




\subsection{Structure model}

The role of structure in the Luise volcano can only be understood in terms of the volcanic processes. Figure 10 presents a schematic cross-section through a strata volcano with the Luise volcanic regions overlain. The regions are schematic and numbered to allow description:

1. Some basement structure is in part reflected up through the volcanic pile. The pre-existing basement structure starts out as significant, but as the volcanic processes continue these structures are extremely modified by volcanism.

2. A central core where the structure has largely been extremely overprinted. Because the volcano shape is conical and there are high pore pressures, the stresses vary around the volcanic edifice. Consequently, the structure within the volcano tends to develop in an approximately circular pattern.

3. The collapse process uses the pre-existing structural fabric, which is modified and extended as the deformation of the volcanic pile develops.

4. The next stage of the process is post-collapse where the phreatomagmatic processes overprint many earlier phases. When the activity starts to wane Crater Lake sediments can accumulate in old explosive vents and diatremes.

5. The volcano flanks remain relatively un-deformed and unaltered by these processes.

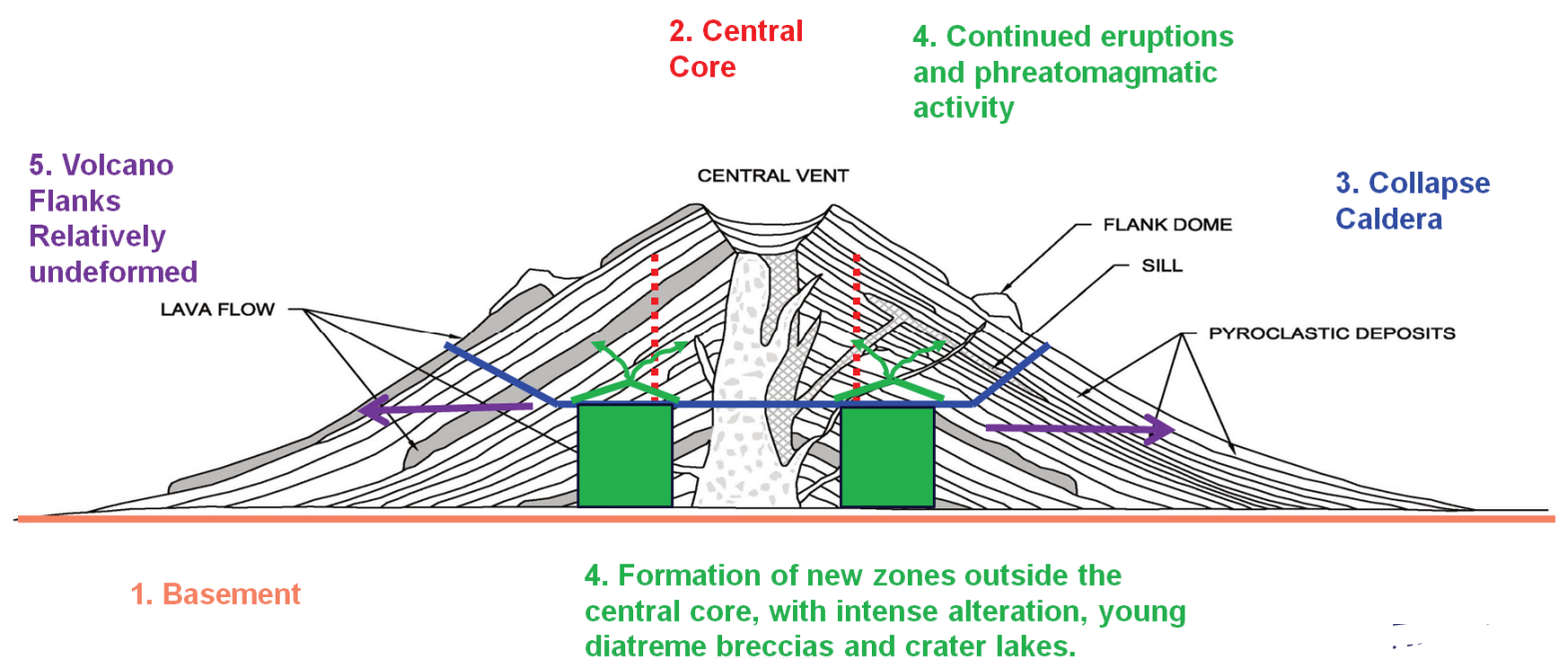

Figure 10 Schematic cross-section showing the volcanic regions and processes of the Luise volcano

Regional basement structures have played a role in mineralisation. They have also played a role more indirectly in sector collapse. Regional basement structures have also played a strong role in the localisation of diatreme intrusions, as discussed previously. A number of historic regional structure models have been developed for Lihir. The structures were typically modelled with strike lengths of many kilometres.

Sector collapse and the subsequent phreatomagmatic effects, including diatremes and alteration, associated with these directions have overprinted and modified these pre-existing structures, at least in the upper levels of the volcanic pile, relevant for pit slope design. Consequently, the structures captured by the large structure models are conceptualised as structural zones with preferred structural fabric that changes according to location within the volcanic pile, rather than as single continuous features important for slope design.

The structural model is based on observations, data and testing of concepts against pit exposures from the past 17 years at Lihir. An existing major structure wireframe model formed the underlying basis, however, it was necessary to evolve the model to a point where it is better conceptualised as combined structural and geotechnical model. The evolution was largely driven by the understanding that the Luise volcano is a very young geological formation and hence the volcanic processes and forms also need to be incorporated into a 
holistic model of understanding. The model was developed understanding the geotechnically important strato-volcano regions as they apply to Luise volcano.

The geotechnical/structure model of the Luise volcano was tested at several scales using high quality data (mapping, photogrammetry and borehole ATV). This showed:

1. Orientations from mapping, photogrammetry and borehole imaging generally fit the broad-scale caldera patterns.

2. Mapped structures are typically limited in length and there are broad structure corridors with longer structures. This was confirmed by correlation between boreholes.

3. There is evidence of large structures being overprinted by the later stage volcanic activity with an increase in shearing.

4. The younger diatremes are likely to have adverse structure and rock mass conditions.

5. Older more consolidated diatremes may influence structure patterns around them.

6. There is no evidence of pervasive shearing directly beneath the Seepage Barrier.

7. Some younger diatremes are present along the Seepage Barrier alignment.

The most important structural elements for the stability of the pit walls are:

- Structures associated with younger diatremes: associated with historic slope failures. Structure orientations within the diatremes are often complex in orientation and shape, making identification of significant structures from borehole data difficult.

- Crater Lake sediments: sub-horizontally bedded with soil strength beds that are persistent over most of the deposit.

This conceptual structure geotechnical model served as the foundation for updating structure domains in the NMA for slope design purposes. The domains reflect the variation in structure patterns and character that are associated with the different geotechnical units. The domains are largely based on the borehole ATV data with confirmation from geotechnical mapping where appropriate. The data for each structural geotechnical domain was used for kinematic and statistical analyses.

\subsection{Groundwater}

Groundwater flow at Lihir is driven by the interplay of rainfall recharge, deep geothermal upflow and the ocean. Due to the elevated rainfall rates occurring in the area, recharge is significant across the entire site. High recharge rates, in conjunction with low permeability units such as the Argillic Zone, result in high pore pressures. These pore pressures were the subject of investigation in the groundwater modelling.

In terms of hydrogeological properties, three major zones can be defined in the Lihir area:

1. An upper low permeability unit comprised the argillic material. This unit covers the entire area with the exception of the caldera rims and the landslide area. Heads are higher in the Argillic than the deeper rocks.

2. An intermediate high permeability unit comprising the transitional alteration zone. Significant areas of the NMA are depressurised in these units. Depressurisation is greatest adjacent to the existing pit. This is significant given that the constant head boundary of the ocean is relatively close by. This would imply there is not a good hydraulic connection under the ocean between the more permeable units at depth and the sea.

3. A lower zone comprising of the anhydrite seal. This unit is expected to have moderate permeability where it interfaces with the Transitional alteration zone. 
Geological units of lesser significance in terms of regional groundwater flow, but of potentially greater importance in terms of slope stability, include the landslide and underlying CLD. The landslide is expected to have moderate to high permeability and elevated recharge rates.

Although the area contains some faults and fracture zones generated by a number of different processes, these structures are impacted by alteration which overprints the entire area. In exposures in the existing pit and within the Argillic Zone the permeability of structures appears low. One exception, however, is the Minifie shear zone located in the southern part of the existing mine, where most of the dewatering abstraction currently occurs.

Deep upflow is resulted from convective groundwater flow and is a major source of heat. The occurrence of upflow zones is structurally controlled and can be observed through elevated temperature values and surface expression of geothermal features. The structural controls appear to be related to the basement, which reflects the regional and tectonic orientations. In the areas where the upflow occurs, the temperature profile is defined by the balance between cold water from rainfall recharge and hot water from upflow. Therefore, low temperature measurements in VWP are either associated with shallower depths or areas where rainfall recharge is significant.

The sea floor to the northeast of the site is a major hydrogeological boundary.

A constant average head of $1,000 \mathrm{mRL}$, with some minor variation due to tidal movements, is observed along the entire sea floor. Prior to the mining activities, the sea was the largest outflow zone where the majority of water from meteoric recharge and deep upflow was discharged.

With the development of pit excavation, hydraulic gradients are diverted towards the pits. The sea, which was originally an outflow zone, becomes a source of low temperature inflow to the aquifers. Sea inflow is expected to increase once pit development intercepts higher permeability units such as the leached soaked domain. The inflow of low temperature seawater is also likely to contribute to decreased temperatures.

Pit excavation has been observed to generate different depressurisation trends as a result of different geotechnical unit permeabilities. Depressurisation in areas of low permeability, such as within the argillics, are expected to be slow while areas of higher permeability such as the transitional units will promote a faster depressurisation.

Pore pressure modelling for slope stability analysis in the 2017-2019 study was conducted using numerous approaches including:

- Waiwera geothermal flow software: large-scale geothermal modelling by University of Auckland.

- An empirical Hu value, using an approach specifically developed for Lihir to take into account temperatures and identify where unusually high pressures may occur due to the occurrence of steam. This has been achieved at Lihir by presenting temperature data in parallel to the pressure along with a benchmark line representing the hypothetical boiling point per depth.

- 2D single phase (i.e. liquid) modelling using SEEP/W with models calibrated against VWP data. The modelled pore pressures appear reasonable in the shallow slopes, where slope stability is most critical.

- Dual phase pore pressure predictions using the finite element heat and mass (FEHM) modelling code. FEHM was developed by the Los Alamos National Laboratory and is designed for analysing a range of multiphase problems including liquid, gas and heat transport. 2D FEHM.

One important conclusion from the pore pressure analyses was that there is not a significant difference between the single phase and dual phase pore pressure predictions. However, the single phase model is considered to have a better overall calibration. All pore pressures models were used in the subsequent stability analyses. 
Surface water management and maintenance is also critical for the performance of the upper slopes in the weaker units. Surface water management and interception shallow groundwater flow are important to control the erosion of long-term slopes.

\subsection{Natural Caldera slopes}

As shown in Figure 2, the Lihir gold mine is located within the amphitheatre of the collapsed Luise volcano, with steep natural slopes that surround the mine to the west and south. The natural slopes are susceptible to landslides and represent a potential risk to mining operations. The natural slopes were reviewed in a desktop study undertaken by PSM in 2018 using existing remote sensing data. The principal objective of the study was to identify and characterise potential failure mechanisms for the natural slopes.

The approach for the study was in general accordance with the Australian Geomechanics Society Guidelines (2007) and is summarised as follows:

1. Development of an engineering geological model, with a focus on terrain evaluation and land facets.

2. Collation of a landslide inventory for the natural slopes.

3. The model and the inventory are then used to identify the primary landslide mechanisms.

4. Landslide zoning of the natural slopes in terms of susceptibility, hazard and risk to property.

5. The zoning results are then used to inform relative the risks to mining operations.

The natural caldera slopes were grouped into three broad zones, which are shown in a conceptual model in Figure 11. Each zone is influenced by different engineering geology conditions and is consequently susceptible to different types of landslide. Three basic landslide mechanisms are identified from the model and landslide inventory: rockfall, shallow surficial and deep mass movements. The areas susceptible to these mechanisms are distributed around the slopes in roughly upper, mid and lower natural slopes, respectively. These zones of susceptibility, particularly those on the lower slopes are an important consideration in the pit slope design.

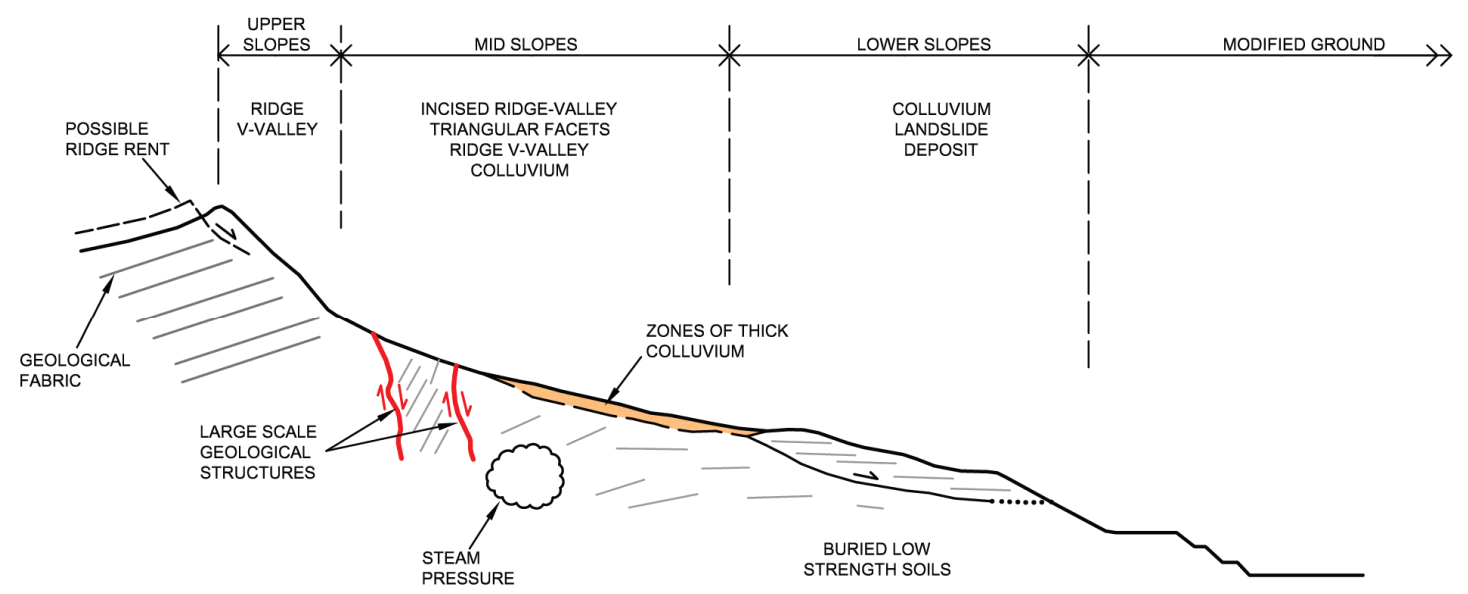

Figure 11 Conceptual model showing typical caldera slope profile and slope features at Lihir

\section{$4 \quad$ Implications for slope design}

From our understanding of geotechnical conditions in the NMA and existing slope performance:

1. Within the main central ore zones and geothermal areas of the caldera, geological structure has largely been destroyed. Thus: 
a. The large persistent 'structures' are represented by zones with less persistent intermittent shears or faults and some alteration.

b. Hence the design case within the higher strength units is stability controlled by isolated faults or shears.

2. The exception to this is the southeast and southwest of wall of the existing pit, where slope performance has been impacted by a continuous fault/shear. This structure is outside the geothermal/alteration zones and believed to be a volcano sector collapse structure.

3. The Argillic unit is of soil to weak rock strength and soil strength mass parameters apply. Pore pressures strongly influence slope performance in these units.

4. The CLD has bedding controlled plane sliding stability considerations.

5. Young diatremes from late stage phreatomagmatic activity are typically fine-grained, with low strength rock mass and sheared contacts. Structures within the diatremes may be flat, curved and low strength.

The proposed pit in the NMA will extend across all of these geotechnical conditions and hence consideration needs to be given to the potential impact of each of these components on stability and design. The stability of the proposed slopes was analysed from both a structural stability and a rock mass point of view.

\section{Conclusion}

This paper has presented the evolution of the geotechnical model for the NMA at Lihir over the past 10 years. The study highlighted the importance of a conceptual model as the first step in any geotechnical model; as it provides a hypothesis that all available data can be tested against.

The geotechnical model at Lihir comprises units that may be grouped into the following broad categories; surficial sediments, lithological and alteration. Of significant importance for slope design are the occurrence of young diatremes and the CLD.

The structure model was developed understanding the geotechnically important strato-volcano regions which have been overprinted and modified by sector collapse and subsequent phreatomagmatic effects. Both the rock mass and structural understanding at Lihir are closely linked to form a complex geotechnical model.

Groundwater flow at Lihir is driven by the interplay of rainfall recharge, deep geothermal upflow and the ocean. Due to the elevated rainfall rates occurring in the area, recharge is significant across the entire site. The groundwater and geothermal conditions are complex, and this makes pore pressure estimations for slope stability some of the most complicated undertaken in modern mining practices around the world.

The geotechnical model for Lihir incorporates the rock mass, structure, pore pressures and natural slopes. In addition, Lihir Island is in a location of high seismicity and the top portions of the pit slopes feature a considerable depth of weak rocks and soils. This has been addressed by numerous project technical studies and not presented here.

\section{Acknowledgement}

The authors of this paper acknowledge the operational cooperation of key Newcrest Mining personnel, particularly Frank Pothitos. Thanks also to Newcrest Mining for permission to publish this paper.

\section{References}

Australian Geomechanics Society 2007, 'Practice Note Guidelines for Landslide Risk Management 2007', Journal of Australian Geomechanics Society, vol. 42, no. 1.

Blackwell, J 2010, Characteristics and origins of breccias in a volcanic-hosted alkalic epithermal gold deposit, Ladolam, Lihir Island, Papua New Guinea, PhD Thesis, University of Tasmania, Hobart. 
Corbett, GJ \& Leach, TM 1998, 'Southwest Pacific rim gold-copper systems: structure, alteration and mineralisation', Society of Economic Geologists, Littleton, Special Publication No. 6.

Gifkins, C, Herrmann, W \& Large, R 2005, Altered volcanic rocks: a guide to description and interpretation, Centre for Ore Deposit Research, Hobart.

Hencher, S 2012, Practical Engineering Geology, Spon Press, New York.

Hunt, AJ 2002, The discovery of structure confined blind ore extensions to the Ladolan deposits, Lihir, PNG, Exploration in the Shadow of the Headframe. North Sydney: Annual Meeting of the Sydney Mineral Exploration Discussion Group, http://www.smedg.org.au/hunt02.pdf

Komyshan, P 1999, Geological interpretations of Lihir Island: Consulting Scientists of Australia (CSA Australia Pty Ltd), unpublished report R8.99, p. 40.

McPhie, J, Doyle, M \& Allen, R 1993, 'Volcanic textures: a guide to the interpretation of textures', Volcanic Rocks, CODES Key Centre, Hobart.

Sillitoe, RH, Baker, E \& Brook, WA 1984, 'Gold deposits and hydrothermal eruption breccias associated with a maar volcano at Wau, Papua New Guinea', Economic Geology, vol. 79, no. 4, pp. 638-655.

Wallace, L, Stevens, C, Silver, E, McCaffrey, R, Loratung, W, Hasiata, S \& Taugaloidi, J 2004, 'GPS and seismological constraints on active tectonics and arc-continent collision in Papua New Guinea: Implications for mechanics of microplate rotations in a plate boundary zone', Journal of Geophysical Research, vol. 109, https://doi.org/10.1029/2003JB002481 
